Sherratt, H. S. A. \& Thomas, A. J. (1953). J. gen. Microbiol. 8, 217-223.

\title{
The Nucleic Acid Fractions of a Strain of Streptococcus faecalis
}

\author{
By H. S. A. SHERRATT and A. J. THOMAS \\ Department of Agricultural Chemistry, School of Agriculture, \\ University College of North Wales, Bangor
}

SUMMARY: The Schmidt \& Thannhauser (1945) procedure was applied to the nucleic acid fractions of Streptococcus faecalis. A part of the deoxypentose nucleic acid was differentiated as being insoluble in $\mathrm{N}-\mathrm{NaOH}$ at $37^{\circ}$, and appeared to be firmly bound to polysaccharide material. Base analyses of the nucleic acid fractions are reported, and qualitative determinations of the amino-acid and sugar composition of the residue described.

The Schmidt \& Thannhauser (1945) procedure has been widely used to estimate the nucleic acids in biological materials. It consists, essentially, of incubating the tissue with $\mathrm{N}-\mathrm{NaOH}$ so that the nucleic acids dissolve and the pentose nucleic acid (PNA) is degraded to nucleotides while the deoxypentose nucleic acid (DNA) is still precipitable by acid. The nucleic acid fractions are then resolved by precipitating the DNA, the PNA nucleotides remaining in the supernatant. We have noted, however, in applying this method to a strain of Streptococcus faecalis, that a large proportion of the DNA, in association with much cell material, remains undissolved in the $\mathrm{N}-\mathrm{NaOH}$. Thus the DNA portion appears to exist in two easily separable fractions.

\section{METHODS}

Preparation of material. Streptococcus faecalis NCIB8123 was grown in a medium comprising $\mathbf{0 . 2} \mathrm{g}$. yeast extract (Oxoid), $0.5 \mathrm{~g}$. peptone (Oxoid), $0.5 \mathrm{~g}$. glucose, dissolved in $100 \mathrm{ml}$. 0.05 M-phosphate buffer and adjusted to pH 7. The organism was grown in 10 l. batches, harvested on a Sharples supercentrifuge, washed twice with water and acetone-dried.

Schmidt \& Thannhauser procedure. A modification of this technique (Davidson, Leslie \& Waymouth, 1949) was used to prepare the nucleic acid fractions. The dried cells were extracted twice with ice-cold $10 \%(\mathrm{w} / \mathrm{v})$ trichloroacetic acid (TCA) in $50 \mathrm{ml}$. centrifuge tubes, then, in succession, with $80 \%(\mathrm{v} / \mathrm{v})$ ethanol, absolute ethanol, chloroform + ethanol $(1: 3)$ twice at $80^{\circ}$, and finally with ether.

The remaining dry powder was incubated overnight with $10 \mathrm{ml} . \mathrm{N}-\mathrm{NaOH}$ at $37^{\circ}$. The insoluble residue was centrifuged off and washed with water (15 ml.) which was added to the supernatant. To this combined aqueous solution, $5 \mathrm{ml}$. of $2.5 \mathrm{~N}-\mathrm{HCl}$ and $6 \mathrm{ml} .30 \%(\mathrm{w} / \mathrm{v})$ TCA were added. The DNA was precipitated and spun down by centrifuging for 20 min. at 5000 r.p.m. The precipitate was washed twice with small volumes of $5 \%$ TCA, the washings being added to the supernatant solution which contained the PNA. This 
solution of PNA was concentrated in vacuo, transferred to a combustion tube and evaporated to dryness in a vacuum desiccator over $\mathrm{P}_{2} \mathrm{O}_{5}$ and solid $\mathrm{NaOH}$; this was the PNA fraction.

The precipitated DNA was dissolved in a small volume of $0 \cdot 1 \mathrm{~N}-\mathrm{NaOH}$ and reprecipitated by acidification with acetic acid and addition of 1 vol. ethanol. The DNA was redissolved in $0 \cdot 1 \mathrm{~N}-\mathrm{NaOH}$ and deproteinized by shaking with chloroform + butanol $(8: 1, \mathrm{v} / \mathrm{v})$. The protein gel was centrifuged off and the DNA precipitated from the aqueous fraction by the addition of acetic acid and ethanol and finally dried with acetone and ether. This was the 'free' DNA fraction.

The insoluble residue from the $\mathrm{N}-\mathrm{NaOH}$ hydrolysis was washed twice with $\mathrm{N}-\mathrm{NaOH}$ and then twice with water. It was finally dried with acetone and ether; this was the 'bound' DNA fraction.

The nucleic acids in the three fractions were assayed by direct phosphorus determinations.

Phosphorus determinations. After combustion with $60 \%(\mathrm{w} / \mathrm{v})$ perchloric acid, inorganic phosphorus was measured colorimetrically by the method of Fiske \& Subbarow (1925).

Nitrogen determinations. Total nitrogen was assayed by a micro-Kjeldahl method.

The Dische reaction for deoxypentoses was carried out qualitatively by heating the sample with two volumes of the Dische reagent (twice recrystallized diphenylamine, $1 \mathrm{~g}$.; sulphuric acid, $1.5 \mathrm{ml}$.; glacial acetic acid, $100 \mathrm{ml}$.) for $20 \mathrm{~min}$. at $100^{\circ}$. A blue colour indicates deoxypentose. The specificity of this test was examined by Deriaz, Stacey, Teece \& Wiggins (1949).

\section{Chromatographic methods}

For nucleic acids the technique of Wyatt (1951) was used. The nucleic acid fractions were hydrolysed by heating with $72 \%(w / v)$ perchloric acid on a boiling water-bath for 90 min., sufficient perchloric acid being used to give an $8 \%$ solution of nucleic acid, calculated from the $\mathbf{P}$ content. The hydrolysate was then diluted with 2 vol. water and centrifuged to remove the carbon. Samples (15-25 $\mu \mathrm{l}$.) of the supernatant liquid were taken for chromatography and for further $\mathbf{P}$ determinations. The chromatograms were run for $36 \mathrm{hr}$. in isopropanol $+\mathrm{HCl}(65: 35, \mathrm{v} / \mathrm{v}$, with $2 \mathrm{~N}-\mathrm{HCl})$ on Whatman no. 1 paper and dried in air.

Purines and pyrimidines were detected by photographing the paper in ultraviolet light on reflex document paper. The source of ultraviolet light used was an Osram UV lamp with the outer glass envelope removed. This was in series with a $3000-0 h m$ resistance (mains voltage $230 \mathrm{~V}$. a.c.) and the light was filtered through an Ilford filter no. 828. This is a method which has been used in this laboratory by Mr R. A. Evans. The positions of the spots were traced out on the chromatogram and the areas cut out and eluted, together with the appropriate blank areas, with $0 \cdot 1 \mathrm{~N}-\mathrm{HCl}$. The bases were estimated by measuring their ultraviolet extinction at their maxima against the extinction of the appropriate blank, in the Unicam spectrophotometer. The identity of 
all the spots was confirmed by determining the ultraviolet absorption curves of the eluates.

Amino-acids. The sample was hydrolysed with $6 \mathrm{~N}-\mathrm{HCl}$ for $16 \mathrm{hr}$, , the hydrolysate evaporated to dryness 3 times in vacuo and taken up in a small volume of water. The hydrolysates were run on Whatman no. 1 paper with $n$-butanol + acetic acid + water mixture $(4: 1: 5, \mathrm{v} / \mathrm{v})$ in one dimension, and in two dimensions with $n$-butanol+acetic acid+water followed by phenol $+\mathrm{NH}_{3}(3: 1 \mathrm{v} / \mathrm{v})$, the $\mathrm{NH}_{3}$ solution being $3 \mathrm{ml}$. sp.gr $0 \cdot 880$ ammonia in $1 \mathrm{l}$. water, using ascending chromatography. The amino-acids were detected by spraying with ninhydrin.

Sugars. The sample was hydrolysed with $2 \mathrm{~N}-\mathrm{H}_{2} \mathrm{SO}_{4}$ in a sealed tube at $100^{\circ}$ for $2 \mathrm{hr}$., the hydrolysate adjusted to $\mathrm{pH} 4.5$ with $\mathrm{Ba}(\mathrm{OH})_{2}$ solution, and the mixture centrifuged. The precipitated $\mathrm{BaSO}_{4}$ was washed, and the hydrolysate + washings evaporated to a small volume in vacuo. The hydrolysate was run with $n$-butanol + acetic acid + water mixture in one dimension, followed by phenol $+\mathrm{NH}_{3}$ in the second. The various sugars were detected by aniline hydrogen phthalate (Partridge, 1949). The presence of rhamnose was confirmed by a specific colour test for methylpentoses (Edward \& Waldron, 1952).

\section{Growth experiment}

One litre of the glucose peptone medium was inoculated with $1 \mathrm{ml}$. of a $24 \mathrm{hr}$. culture of Strep. faecalis and incubated aerobically at $37^{\circ}$. At hourly intervals $10 \mathrm{ml}$. samples were withdrawn, centrifuged and the cells washed. The cells were resuspended in $10 \mathrm{ml}$. water and $1 \mathrm{ml}$. of this taken and appropriately diluted for turbidity measurements. To the remaining $9 \mathrm{ml}$., $1 \mathrm{ml}$. of $\mathrm{N}-\mathrm{NaOH}$ was added and the suspension incubated at $37^{\circ}$ overnight. The residue was then spun down and the ultraviolet absorption of the supernatant read directly in the Unicam spectrophotometer, at its maximum absorption at $260 \mathrm{~m} \mu$. This represents the PNA + 'free' DNA. The residue ('bound' DNA) was hydrolysed with $72 \%$ perchloric acid at $100^{\circ}$ for $1 \mathrm{hr}$, diluted to $10 \mathrm{ml}$., the carbon fragments centrifuged down and the ultraviolet absorption of the resulting clear solution measured at its absorption peak of $260 \mathrm{~m} \mu$. The absorption curves of the two components were measured and conformed to the normal curve for a nucleic acid, thus showing them to be free from appreciable quantities of other ultraviolet absorbing substances.

\section{RESULTS}

The quantitative results are expressed as the means of triplicate determinations on three independent preparations.

'Bound' $D N A$ fraction. This is insoluble in $\mathrm{N}-\mathrm{NaOH}$ at $37^{\circ}$. The cell outlines were still visible and were Gram-negative. The material had $\mathbf{P}=1 \cdot 05 \%$ and $\mathrm{N}=3.85 \%$ and represented $45 \%$ of the cell dry weight. Adenine, guanine, cytosine and thymine were detected and accounted for $78 \%$ of the $\mathbf{P}$ in the fraction, assuming that the bases in nucleic acids have a 9:10 molar ratio to $P$ (Wyatt, 1951). 
The following compounds were also detected in hydrolysates:

(a) Amino-acids : alanine, aspartic acid, glutamic acid, glycine, leucine, lysine, phenylalanine, threonine, tyrosine, valine.

(b) Sugars: galactose, glucose and rhamnose. The fraction gave a strong Dische reaction for deoxypentose.

Extraction of the fraction by boiling $\mathrm{N}-\mathrm{NaOH}$ gradually removed $\mathrm{P}$ from the material, although after four successive $15 \mathrm{~min}$. extractions some $10 \%$ of the $\mathbf{P}$ still remained in the residue. The $\mathbf{P}$ in the supernatants from each successive extraction was found to be almost equally distributed between the acid-soluble and acid-insoluble material. At the same time much of the carbohydrate became soluble in the $\mathrm{N}-\mathrm{NaOH}$, at a rate corresponding to the extraction of the $\mathrm{P}$. Chromatography showed that purine and pyrimidine bases were also distributed between the acid-soluble and acid-insoluble material.

'Free' $D N A$ fraction. The bases adenine, guanine, cytosine and thymine were detected; they accounted for $95 \%$ of the $\mathrm{P}$ of the fraction.

$P N A$ fraction. The bases adenine, guanine, cytosine and uracil were detected; they accounted for $85 \%$ of the $\mathbf{P}$ of the fraction. No inorganic $\mathbf{P}$ was detected.

Whole cells. Values for the $\mathbf{P}$ content of the different nucleic acid fractions were: 'bound' DNA 4.75 $\mu \mathrm{g} . / \mathrm{mg}$.; 'free' DNA 1.03 $\mu \mathrm{g} . / \mathrm{mg}$.; PNA $11.6 \mu \mathrm{g} . / \mathrm{mg}$. The purine and pyrimidine composition of the fractions is given in Table 1. The following compounds were detected in hydrolysates of the whole organism:

(a) Bases: adenine, guanine, cytosine, uracil, thymine.

(b) Amino-acids: alanine, arginine, aspartic acid, glutamic acid, glycine, histidine, leucine, lysine, phenylalanine, proline, serine, threonine, tyrosine, valine.

(c) Sugars: galactose, glucose, glucosamine, ribose, rhamnose.

Table 1. The purine and pyrimidine composition of the nucleic acid fractions of washed Streptococcus faecalis

\begin{tabular}{|c|c|c|c|}
\hline \multirow[b]{2}{*}{ Base } & \multicolumn{3}{|c|}{ Molar ratios, calculated to total 4.0} \\
\hline & $\begin{array}{c}\text { 'Bound' } \\
\text { DNA }\end{array}$ & $\begin{array}{l}\text { 'Free' } \\
\text { DNA }\end{array}$ & PNA \\
\hline Adenine & $1 \cdot 17$ & $1 \cdot 20$ & $1 \cdot 00$ \\
\hline Guanine & 0.73 & $0 \cdot 66$ & $\mathbf{1} \cdot \mathbf{2 5}$ \\
\hline Cytosine & $0 \cdot 81$ & 0.84 & $0 \cdot 61$ \\
\hline Uracil & - & - & $1 \cdot 14$ \\
\hline Thymine & 1.29 & $1 \cdot 30$ & - \\
\hline
\end{tabular}

Results of the growth experiment

The results of the growth experiment are shown in Fig. 1. The amount of bacterial growth was measured by a photo-electric turbidimeter. The relation of this to weight of cell material and to cell numbers once the log phase is reached has been tested by a number of workers (Monod, 1942). The nucleic acid curves were obtained by dividing the ultraviolet absorption by the 
turbidity, and thus give a measure of the variation of the amount of nucleic acid/cell during the lag and early log phases, when the mean cell size remains approximately constant. The insoluble fraction persists throughout the growth cycle after the initiation of the log phase and remains proportional to the amount of soluble nucleic acid in the cell. The 'bound' DNA fraction also persists under differing physiological and nutritional conditions (Thomas, unpublished).

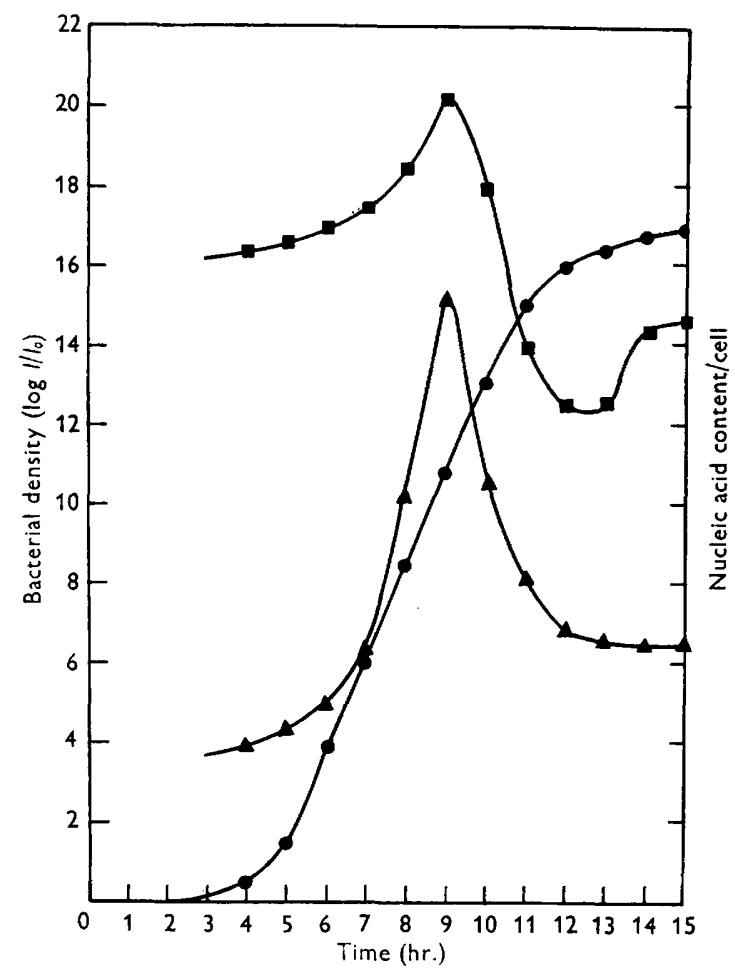

Fig. 1. The variation of the nucleic acid fractions of Streptococcus faecalis during growth.

- bacterial density, measured turbidimetrically, $\log I / I_{0} ; \Delta-\Delta=$ 'bound'
DNA/cell $=$ ultraviolet absorption at $260 \mathrm{~m} \mu$. divided by turbidity; DNA/cell = ultraviolet absorption at $260 \mathrm{~m} \mu$. divided by turbidity;
DNA/cell = ultraviolet absorption at $260 \mathrm{~m} \mu$. divided by turbidity.

\section{DISCUSSION}

The drastic conditions necessary for extraction of 'bound' DNA from the cells lead to partial degradation of the DNA to smaller acid-soluble molecules with a simultaneous extraction of carbohydrate. This suggests that the more insoluble DNA fraction is part of a stable complex. If DNA were linked to polysaccharide by ester links between the primary phosphate groups of the DNA and the hydroxyl groups of the sugar residues such a stable complex would be expected. Such esterification of DNA might replace, wholly or in part, electrovalent links to the basic groups of proteins. Purified DNA, extracted from Haemophilus pertussis, still contains $33 \%$ of carbohydrate (Overend, Stacey, Webb \& Ungar, 1951), and carbohydrate is associated 
with DNA isolated from rye (Laland, Overend \& Webb, 1950). This association of DNA with carbohydrate may be of significance in view of the changes in the serologically active polysaccharide of pneumococci induced by a purified pneumococcal DNA preparation (Avery, MacLeod \& McCarty, 1944).

The complex nature of the 'bound' DNA fraction is indicated by the presence of amino-acid and sugar residues. (The finding of purines and pyrimidines, $\mathbf{P}$ and deoxypentose is regarded as demonstrating the presence of DNA. This does not, of course, rigidly prove that these components are linked as in DNA). Salton (1952) described the chemical composition of cell walls obtained from Streptococcus faecalis by mechanical disintegration. These were largely insoluble in alkali and yielded amino-acids and sugars on hydrolysis. The ultraviolet absorption of the cell-wall suspension gave no evidence for the presence of nucleic acid though the preparation contained $1 \cdot 8 \% \mathrm{P}$. Our alkali-insoluble residue must contain much somatic material in addition to the cell wall.

There does not seem to be any significant difference in the purine and pyrimidine composition of the two DNA fractions. Both are in the AT (excess adenine and thymine) 'animal' class in contrast to the GC (excess guanine and cytosine) class which Chargaff, Zamenhof, Brawerman \& Kerin (1950) have reported for some bacterial DNA preparations.

The chromatographic evidence confirms the validity of the Schmidt \& Thannhauser procedure for the separation of the extracted nucleic acids. The finding of ribose in the whole cell is consistent with the presence of a pentose nucleic acid. Most of the $\mathbf{P}$ in the 'free' DNA fraction is accounted for by the purines and pyrimidines. The 'bound' DNA has $22 \%$ excess $\mathbf{P}$ and the PNA fraction $15 \%$ excess. Mitchell \& Moyle (1950) reported that c. $70 \%$ and c. $93 \%$, respectively, of the $\mathbf{P}$ in two strains of Strep. faecalis was accounted for by the nucleic acid ultraviolet absorption.

These observations draw attention to the necessity of examining any alkali-insoluble residue, obtained in the Schmidt \& Thannhauser procedure, for the presence of nucleic acid.

The authors wish to thank Prof. W. Charles Evans for his interest and encouragement, and Dr W. J. Whelan for helpful advice. We also thank the Agricultural Research Council for their financial support.

\section{REFERENCES}

Avery, O. T., Macleod, C. M. \& McCarty, M. (1944). Studies on the chemical nature of the substance inducing transformation of pneumococcal types. Induction of transformation by a deoxyribonucleic acid fraction isolated from pneumococcus Type III. J. exp. Med. 79, 137.

Chargaff, E., Zamenhof, S., Brawerman, G. \& Kerin, L. (1950). Bacterial deoxypentose nucleic acids of unusual composition. J. Amer. chem. Soc. 72, 3825.

Davidson, J. N., Leslie, I. \& Waymouth, C. (1949). The nucleoprotein content of fibroblasts growing in vitro. 4. Changes in the ribonucleic acid phosphorus (RNAP) and deoxyribonucleic acid phosphorus (DNAP) content. Biochem. $J$. 44, 5 . 
Deriaz, R. E., Stacey, M., Teece, E. \& Wiggins, L. F. (1949). Deoxysugars. Part I. The Dische reaction for 2-deoxypentoses. J. chem. Soc. p. 1222.

EDward, J. T. \& Waldoron, D. M. (1952). The detection of deoxysugars, glycols, and methyl pentoses in paper partition chromatography. J. chem. Soc. p. 3631 .

Fiske, C. H. \& Subbarow, Y. (1925). The colorimetric determination of phosphorus. J. biol. Chem. 66, 375.

Laland, S. G., Overend, W. G. \& WebB, M. (1950). The isolation of deoxyribonucleic acids from rye and wheat germ. Acta chem. scand. 4, 885 .

Mitchell, P. \& Moyle, J. (1950). Occurrence of a phosphoric ester in certain bacteria: its relation to Gram staining and penicillin sensitivity. Nature, Lond. $166,218$.

Monod, J. (1942). La Croissance des cultures bactériennes, p. 38. Paris: Hermann et Cie.

Overend, W. G., Stacey, M., Webb, M. \& Ungar, J. (1951). The isolation of deoxyribonucleic acid from virulent and avirulent strains of Haemophilus pertussis. J. gen. Microbiol. 5, 268.

Partridge, S. M. (1949). Aniline hydrogen phthalate as a spraying reagent for chromatography of sugars. Nature, Lond. 166, 443.

Salton, M. R. J. (1952). Studies on the bacterial cell wall. III. Preliminary investigations of the chemical constitution of the cell wall of Streptococcus faecalis. Biochim. biophys. Acta, 8, 510.

Schmidt, G. \& Thannhauser, S. J. (1945). A method for the determination of deoxyribonucleic acid, ribonucleic acid, and phosphoproteins in animal tissues. J. biol. Chem. 161, 83.

WyatT, G. R. (1951). The purine and pyrimidine composition of deoxypentose nucleic acids. Biochem. $J .48,584$.

(Received 8 August 1952) 